hospital admissions in sevoral Caribbean territories, and tho closure of severe traumatic wounds wore road by Dr. G. H. Wattley and Mr. L. L. S. Robertson respoctively, from Trinidad. Dr. P. Curzon reported results of invostigations of enzyme histochemistry of ninety-two placentao obtained from normal and abnormal pregnancies of different stages of gestation. Tho author suggested that a high concontration of alkaline phosphatase and glucose-6phosphatase together with a low concontration of acid phosphatase constituted the histochemical parameters of placental insufficioney.

A papor by Dr. J. B. Davies of the Sandfly Roscarch Unit, Jamaica, domonstrated that the emergence rates of throe specios of Culicoides were closely related to the tidal amplitude and mean weekly tide-levols, thus establishing that control of those insocts would be brought about by water managemont mothods. Dr. T. Poon-King (Trinidad) reported on an epidemic of acute glomorulonophritis which occurred recently in South Trinidad. Two hundred and ninety-soven pationts wero admitted to hospital, and children 3-9 years of age were most froquontly affected.
'Three-quarters of all patients were East Indians and tho incidence was considerably higher in rural than in urban areas. Oodemo was the presenting symptom in all cases, and whereas fow patients gave a history of procoding sore throat, many had septic skin losions $1-4$ weeks befor: the onset of oedema. Group $A \beta$-haemolytic stroptococei were isolated from the skin and throat of a ropresontativo sample of nephritic patients. Dr. D. A. Gale presented the findings of a retrospective study of anaphylactoid reactions occurring in Barbados. This survey revoalod that ninetytwo reactions were reported by forty-two doctors and the number of reactions appearod to be on the inerosse. Ponicillin was the antigenic agent in 57 por cent of cases, tho second cornmonest causo boing ATS and other antisera (28 per esnt of eases). Five of these reactions wore fintal. Dr. Cale bolieves that few doctors practising in the area appear to be adequately propared to deal with this medical emergency. ITo concluded with a discussion of presont. day tosting procedures to detoct potontial reactors, prophylactic measures and troatment of an anaphylactoid reaction.

\title{
CANADIAN ANTHROPOLOGY
}

$\mathrm{T}$ HE National Muserum of Canada has rocontly published, in its Anthropological Series, Newfourdland 1)orset Eskimos ${ }^{1}$, by Dr. Elmer Harp, jun., which is based on work carried out by him in 1949 and 1950. It had been submitted to Harvard University as a Ph.D. thosis in 1952 , and is now published without substantial alteration bectuse it is a fundnmontal contribution to tho undorstanding of tho Cape Dorset culture. It is eloarly right that this source matorial should bo available, in spite of the many advanees of knowledge since the thesis was writton.

It consists of an historical introduction and a deseription of the sites and matorials, followed by chapters which comparo tho varions sitos showing the Newfoundland Dorsot to be a unit, and relate this to the Dorset culture elsewhere. Thero is a briof roforence to non-Dorset sites on the Island, and they are shown to be reluted to the Laurentian aspect of the north-eastern Archaic of North America, and aro tontativoly ascribed to the Beothuk Indians, but Dr. Harp does not think that thore ean have been much contact botween the Beothuk and Dorset peoples.

Compurison with Dorset sites outside Newfoundland was somewhat hindered by the state of knowledge at the time of writing, and the publications available. Thus, several of the sites mentioned belong to the Sarqaq enlture, which is now recognized as a pre-Dorset unit containing somo non-Dorset traits. Rowley's doseription of the $\Lambda$ bverdjar Dorset site (American Anthropologist (N.S.), 42, 490; 1940) does not atternpt to bo oxhaustivo and some traits are omitted, so Dr. Harp was unable, for cxample, to include the site among those yielding chippod stone snub-nosed scrapers although there aro soveral good eximplos in Rowloy's colloction at Cambridge. Dr. Harp did not always mako the best of the data he had, becuuse he also omitted A.bverdjar from the sites having triangular: projortils points with conenvo base on p. 115, whoreas he rightly included this trait in the description of the sito on p. 101.

Although his dating ostimates woro far too late in the light of the knowledgo now available, Harp already folt in 1952 that the Denbigh Flint Complex of Alaska was the souren of somn oloments of the Dorsot culture, a view which has recently been reinforced by J. L. Giddings, who discovered Denbigh (The Archaeology of Cape Denbigh, Brown University Pross, 1964). Tt snems likely that some of theso features may have been transmilted by way of pre-Dorset cultures like Sarqag and that recently found on Victoria Island (An Interim Account of Archaeological
Survey in the Central Arctic, 1963, by W. E. Taylor, jun., in Anthropological Papers of the University of Alaska, 12, No. $1 ; 1964$ ), although true Dorset sites are being found further and further west, such as that at Bernard Harbour, about $115^{\circ}$ west, which oxtonds its range 400 miles in that direction (W. F. Taylor, jun., ibid.).

Harp has carried out furthor work in Nowfoundland and the adjacerst parts of Tabrador in 1961 , and further publications aro promised. A first instalment is alrondy available, namely, Evidence of Boreal Archaic Culture in Southern Labrador and Neufoundland, which is one of several papors on diverse subjects, mostly of more loosl intorest, in Part I of Contributions to Anthropology, 1961-62 (ref. 2). This gives further information about the non-T)orsot materinl already mentioned, recording many moro sites and illustrating moro objects. 'The only material found consists of stone tools and weapons, mostly colloctod on the surface, but it adds a good deal to the assemblage previously reportod, and the only comment I would make is that I find it difficult from the illustrations to distinguish between some Dorset and some Boroal Archaic side-notched points.

An attempt is made to seriate the sites in order of age, distinguishing a possible pre-Boreal Archaic stage from the main group, but the evidence is rather thin. In the absence of any proof of Boothuk occupation of particular sites, it is now contionsly suggosted that the Borenl Arehaic in this area is the base from which the historic Beothuk culture ultimatoly evolved.

Liko Part 1, Part 2 of the Contributions to Anthropology, 1961-62 (ref, 3) contains papers on a variety of subjocts. Among those likely to bo of particular interest to readers outsido Canada aro a study of nino North-west Coast 'coppors', in which it is shown, contrary to expostation, that all these examples woro made of copper plato of Whito origin and not of native copper, and two papers on the manufacture and use of kayaks in tho Belchor Islands, North-west 'T'orritories, and at Ivuyivik in the Provines of Quobec. All in all, these volumes are evidence of groat activity in research by the Musoum.

\section{H. S. Bushnet.t,}

\footnotetext{
National Museum of Canada. Bulletin No. 200. Anthropologrical Series. Newfoundland Dorsel Fskimos, 1984. Flmer Harp, jun. Pp. vi +110 (Ottawa Queen's Printer, 1964.) 3 idollars.

${ }^{2}$ Sational Museum of Cannda. Bullotin No. 193 (Anthropolugial Series, No. 01). Contrilutions to Anthropolsgy, 1961-62, l'art 1, P'p. viii + 201 (53 plates). (Ottawa: Queen's 1'rinter, 1964.) 3 dollars.

National Museum of Canada. Bulletin No. 194 (Anthromolegical Series, No. 32): Contributions to Anthromolom, 1961-62, Part 2 . Pp. iv +280
} (Ottawa: Quepn's Printer, 1964.) 3.50 dollars. 